Summer 2013

\title{
Can You Hear Me Now?: Making Participatory Governance Work for the Poor
}

Jaime Alison Lee

University of Baltimore School of Law, jlee@post.harvard.edu

Follow this and additional works at: http://scholarworks.law.ubalt.edu/all_fac

Part of the Law and Economics Commons, and the Social Welfare Law Commons

\section{Recommended Citation}

Can You Hear Me Now?: Making Participatory Governance Work for the Poor, 7 Harv. L. \& Pol'y Rev. 405 (2013)

This Article is brought to you for free and open access by the Faculty Scholarship at ScholarWorks@University of Baltimore School of Law. It has been accepted for inclusion in All Faculty Scholarship by an authorized administrator of ScholarWorks@University of Baltimore School of Law. For more information, please contact snolan@ubalt.edu. 


\title{
"Can You Hear Me Now?": Making Participatory Governance Work for the Poor
}

\author{
Jaime Alison Lee* \\ I. INTRODUCTION
}

Participatory governance engages people who are affected by a problem in the process of solving it. A participatory-governance approach to innercity crime, for example, might include local residents in the process of designing a community-policing program. ${ }^{\perp}$ A community health center might place patients on its board of directors since they have unique knowledge about how the center can better serve those under its care. ${ }^{2}$

In recent decades, courts, legislatures, administrative agencies, and other institutions all have used participatory-governance approaches to tackle complex problems of law and public policy. Legal scholars have observed participatory-governance principles at work in fields as diverse as financial regulation, ${ }^{3}$ public-education reform,${ }^{4}$ and poverty law, ${ }^{5}$ and have identified certain principles as common to these initiatives, which are sometimes referred to collectively as the "New Governance" movement. ${ }^{6}$

\footnotetext{
* Assistant Professor of Law and Director of the Community Development Clinic at the University of Baltimore School of Law. I am grateful for the support of Audrey McFarlane, Susan Bennett, Michele Gilman, Lydia Nussbaum, my research assistants, Lauren Bell and Gregory Fox, and the University of Baltimore.

${ }^{1}$ See, e.g., Michael C. Dorf \& Charles F. Sabel, A Constitution of Democratic Experimentalism, 98 COLum. L. Rev. 267, 328-32 (1998); Kami Chavis Simmons, New Governance and the "New Paradigm" of Police Accountability: A Democratic Approach to Police Reform, 59 CAit. U. L. Rev. 373 (2010).

${ }^{2}$ See generally Yolonda Y. Campbell, New Governance in Action: Community Health Centers and the Public Health Service Act, 4 St. Lous U. J. Hгaith L. \& Por'y 397 (2011).

${ }^{3}$ See Cristie Ford, New Governance in the Teeth of Human Frailty: Lessons From Financial Regulation, 2010 WIs. L. RJiv. 441.

${ }^{4}$ See Dorf \& Sabel, supra note 1, at 328-32.

${ }^{5}$ See David A. Super, Laboratories of Destitution: Democratic Experimentalism and the Failure of Antipoverty Law, 157 U. PA. L. Rrv. 541 (2008).

${ }^{6}$ In the seminal work that gave rise to the umbrella term "New Governance," Orly Lobel identified eight unifying characteristics among strains of thought previously presented under twenty-three separate labels:
}

reflexive law, soft law, collaborative governance, democratic experimentalism, responsive regulation, outsourcing regulation, reconstitutive law, post-regulatory law, revitalizing regulation, regulatory pluralism, decentering regulation, meta-regulation, contractarian law, communicative governance, negotiated governance, destabilization rights, cooperative implementation, interactive compliance, public laboratories, deepened democracy and empowered participatory governance, pragmatic lawyering, nonrival partnership, and a daring legal system.

Orly Lobel, The Renew Deal: The Fall of Regulation and the Rise of Governance in Contemporary Legal Thought, 89 Minn. L. Rev. 342, 384 (2004) (footnotes omitted) (internal quotation marks omitted). This article, like many others, employs the umbrella term "New Governance" for convenience, while acknowledging that this term may be overbroad, see gen- 
Among the core principles of the New Governance model are a commitment to decentralized problem solving by local stakeholders, and the ongoing adjustment of rules and policies informed by on-the-ground monitoring and feedback, also referred to as "learning by doing." " In both of these components of the New Governance process, stakeholder participation plays a critical part.

The New Governance model is often contrasted with the "commandand-control" governance model, which emphasizes centralized, top-down decision making and static rules. The New Governance model poses benefits as well as risks. Some scholars herald its potential to improve legal and policy outcomes, increase institutional accountability, empower marginalized groups, and further democratic ideals of self-determination and equality. Yet others worry that it can also be used to promote grave ills, such as the capture of public power by private interests, the evasion of accountability, and the deepening subordination of already marginalized communities.

What distinguishes these two alternate visions of New Governance? In part, the distinction may lie in whether marginalized stakeholders-those who traditionally have had little influence on matters of governance and who are subject to subordination under the systems under reform-can meaningfully participate in the process. Marginalized stakeholders can offer valuable new information and perspectives, and can increase accountability by serving as a check on established interests. On the other hand, when marginalized stakeholders do not actually influence the outcome, the participatory process becomes merely "cosmetic" and affirmatively subverts the good-governance aims that it is meant to achieve.

Scholars have observed the phenomenon of the cosmetic process in a wide range of settings, and have decried its corrupting effects on New Governance systems and on other kinds of participatory processes. The problem is especially acute when poor people are involved, since they face particularly steep barriers to meaningful participation. Proposals to thwart cosmetic processes are scattered throughout the literature, but there exists no concep-

erally Bradley C. Karkkainen, "New Governance" in Legal Thought and in the World: Some Splitting as Antidote to Overzealous Lumping, 89 MrNN. L. Rrv. 471 (2004) (criticizing the use of the general term "New Governance" in place of naming the specific nomenclature), and that many of the works cited herein relate to specific strains of thought within the New Governance umbrella, such as democratic experimentalism, see, e.g., Charles F. Sabel \& William H. Simon, Minimalism and Experimentalism in the Administrative State, 100 GEO. L.J. 53 (2011) (defining "democratic experimentalism" and arguing for its application in certain contexts). This article, like others, also uses the broader term "participatory governance" where appropriate. It also cites to many works that are not explicitly identified with the New Governance movement or that pre-date the terminology, since many of the concerns and issues implicated are not solely concerns associated with the New Governance movement, such as the problems of meaningful participation by marginalized stakeholders and institutional accountability.

${ }^{7}$ These elements are most essential to the purposes of this article. Scholars have developed various formulations. See, e.g., Lobel, supra note 6, at 405 (describing eight organizing principles among different strains of thought); Sabel \& Simon, supra note 6, at 79 (describing four principles of democratic experimentalism). 
tual framework for how to better promote meaningful participation by marginalized stakeholders. Nor is there a coherent theory for why one system might result in meaningful participation when another may be highly susceptible to producing a cosmetic result.

This article proposes to fill both of these gaps. It does so by drawing a seemingly unlikely parallel between participatory-governance systems and business transactions. It posits that two conditions exist in prospective business transactions: first, all participants must be motivated toward a common goal, and second, they must recognize what the other participants contribute to that goal. These two conditions are necessary before prospective partners will strive toward agreement on the business terms.

The article posits that these same two conditions must exist among participants in a New Governance process in order for meaningful participation to occur. These two conditions are not sufficient to guarantee that meaningful participation will occur, but they are necessary for it to be possible. Thus, the two conditions are the baseline or threshold conditions that must exist before a New Governance process that purports to include poor people can be conducted with integrity.

Articulating the baseline conditions leads to a clearer conceptual understanding of why cosmetic participation occurs, and also offers a structural framework for identifying how to combat it. This framework explains how court-based New Governance processes attempt to combat cosmetic participation-as well as how meaningful participation can be promoted in New Governance systems taking place outside the courtroom, which are especially susceptible to producing cosmetic results.

The framework also supports a baseline theory of prevention against cosmetic processes that aids in distinguishing when the New Governance approach may be suitable as a problem-solving method and where it should be rejected because it carries too high a risk of producing a cosmetic result.

Part II of this article illustrates the New Governance approach and emphasizes the role that marginalized groups play in improving outcomes and enhancing accountability. It also explains the problem of cosmetic participation and why systems that involve poor people are especially susceptible to it.

Part III explains how New Governance theory envisions meaningful participation by marginalized stakeholders taking place, and articulates the baseline-conditions framework as a necessary supplement to that vision. It further explains how courts that apply New Governance methods promote the baseline conditions.

Part IV turns to New Governance systems that take place outside of the courtroom. It analyzes, through the lens of the baseline-conditions framework, a variety of proposals intended to promote meaningful participation. It argues that the active promotion of meaningful participation is necessary and that where it cannot be actively promoted, the New Governance approach should likely be rejected in favor of another problem-solving method. 


\section{The New Governance Approach and the Problem of Cosmetic Participation}

A few brief examples illustrate some key New Governance principles and the broad range of contexts in which the New Governance approach has been applied. A discussion of some of its potential advantages follows, as does an exploration of the problem of cosmetic participation.

\section{A. The New Governance Approach: Overview}

A case study first mentioned by Professor Kami Chavis Simmons illustrates certain key elements of the New Governance model. ${ }^{8}$ In 2001, Cincinnati suffered three days of violent protests after city police killed the fifteenth African American citizen within a six-year time span. ${ }^{9}$ Lawsuits followed, and a federal judge encouraged the litigants in one of the casesthe city, the American Civil Liberties Union, and a local organization representing African American interests-not to pursue the litigation, but instead to settle the case by negotiating their own vision of police reform. ${ }^{10}$

The parties agreed with the court's suggestion and invited the police union to join the discussions. ${ }^{11}$ They collaboratively developed an extensive participatory-governance process that was documented in a settlement agreement and implemented over a multiyear timespan. The process sought input from a criminologist as well as from eight affinity groups representing stakeholders from across the city: African Americans, other minority groups, whites, leaders in business, foundations and educational institutions, youth, social-service organizations, and members of the police force and their families. ${ }^{12}$ Over 3500 stakeholders participated through affinity-group meetings, surveys and questionnaires, small roundtable discussions, and an advisory council. ${ }^{13}$

The process also established an ongoing "evaluation protocol" to monitor whether the goals of the settlement were being met. ${ }^{14}$ The monitoring process required the extensive use of stakeholder surveys to provide data and

${ }^{8}$ Simmons, supra note 1.
${ }^{9}$ See id. at $412,423-24$.
${ }^{10} \mathrm{Id}$. at 424.
${ }^{11} \mathrm{Id}$.
${ }^{12} \mathrm{Id}$. at $424-25$.
${ }^{13}$ Collaborative Agreement para. 4 , In re Cincinnati Policing, No. C-1-99-317 (S.D. Ohio May 3, 2001), available at http://www.cincinnati-oh.gov/police/linkservid/27A205F1-69E9-44 46-BC18BD146CB73DF2/showMeta/0/.

${ }^{14}$ The "evaluation protocol" requires

a broad review of whether the goals of the Collaborative are being achieved. The Evaluation Protocol calls for an extensive research effort, including four types of surveys, an analysis of traffic stops to determine whether there are any patterns of racial bias, reviews of videotaped interactions between police and motorists during traffic stops, periodic observations of CPOP (community problem-oriented policing) meetings, and a review of police statistical data and staffing. 
feedback, with special measures taken to include those with no fixed addresses ${ }^{15}$ and those stopped and questioned by police or arrested. ${ }^{16}$

This brief narrative introduces some of the key elements of the New Governance model: the participation of a broad array of stakeholders in a decentralized problem-solving process, ${ }^{17}$ and the notion of "learning by doing." 18

The Cincinnati process reflects New Governance's emphasis on broadly inclusionary, decentralized problem solving in that the litigants directly engaged with each other, rather than depending on the court to come up with a solution, and also engaged a wide range of stakeholders from across the city.

Inclusive, decentralized processes reflect the idea that all stakeholders affected by a problem should be engaged in the process of solving it. ${ }^{19}$ This is in part to promote democratic ideals ${ }^{210}$ and in part because local stakeholders possess valuable knowledge about the nature of the problem, its causes, and its solutions, ${ }^{21}$ which traditional "command-and-control" decision makers, such as judges or bureaucrats, lack.

The involvement of marginalized stakeholders is especially critical to accountability. ${ }^{22}$ Marginalized stakeholders are uniquely positioned to offer

K. Jack Rit j.y et ai, Pot.tce-Community Rti.ations in Cincinnati 351 (2005), available at http://www.cincinnati-oh.gov/police/linkservid/98744952-464A-462B-8FCC84AE005BFC CD/showMeta/0/.

${ }_{15}$ Collaborative Agreement, supra note 13, para. 35(a).

${ }^{16} I d$. para. 35 (b).

${ }^{17}$ See Sabel \& Simon, supra note 6, at 79 (noting that decentralization can occur at many levels: from the federal government to state governments, from local governments to regulated private entities or private contractors hired by the government, from the national office of a private organization to a local chapter, from a state administrative office to regional districts, or from a school district to individual schools).

${ }^{18}$ Ford, supra note 3 , at 446.

${ }^{19}$ See, e.g., Tara J. Melish, Maximum Feasible Participation of the Poor: New Governance, New Accountability, and a 21st Century War on the Sources of Poverty, 13 YALE Hum. RTS. \& DEV. L.J. 1, 58 (2010) (encouraging that "the needs, experiences, and priorities of those most affected by social welfare policy [be] taken directly into account as a mandatory part of policy formulation and assessment").

${ }^{20}$ Charles Sabel and Michael Dorf define the aim of democratic experimentalism as

to change the reasons and evidence produced in public debate, and with them the conditions for participation in civic life, so that our disputatious democracy is made both more effective as an instrument of public problem solving and more faithful to its purpose of assuring the self-determination of free and equal citizens.

Dorf \& Sabel, supra note 1, at 288-89; see also, e.g., Lobel, supra note 6, at 384 ("The aspiration of the governance model is that increased engagement will contribute to the building of deliberative and collaborative capacities, thus sustaining an environment for democratic engagement.").

${ }_{21}$ See, e.g., Sabel \& Simon, supra note 6, at 90 (noting that the "active participation of beneficiaries" in social-welfare programs may be necessary "because effective intervention depends on their cooperation or because they have information essential to the diagnosis and planning"); Richard B. Stewart, Reconstitutive Law, 46 MD. L. REv. 86, 90 (1986) (describing how certain rules allow for "a measure of discretion that permits incorporation of subsystem interests and values in decisions").

${ }_{22}$ See Wendy A. Bach, Governance, Accountability, and the New Poverty Agenda, 2010 WIs. L. Rev. 239, 292 [hereinafter Bach, Governance]; Wendy A. Bach, Welfare Reform, Privatization, and Power: Reconfiguring Administrative Law Structures From the Ground Up, 
new information, perspectives, and ideas, as well as to serve as a check on more established actors who might otherwise use New Governance processes to further regulatory capture..$^{23}$

Also illustrated by the Cincinnati process is the New Governance principle of "learning by doing." The evaluation protocol included continual scrutiny and adjustment of on-the-ground practices in order to fix mistakes, accommodate new information, and adapt to changing circumstances. ${ }^{24}$ Learning-by-doing couples experimentation with monitoring, and is meant to create a continuously "self-improving" system, in contrast to commandand-control rules that remain largely static..$^{25}$

Learning-by-doing is to be applied not only on a local level; rather, the New Governance model envisions the scaling up and standardization of successful local programs and best practices, so that other jurisdictions can benefit from local experimentation. ${ }^{26}$

Learning-by-doing is meant to improve outcomes and increase accountability through continuous monitoring and feedback. ${ }^{27}$ The participation of marginalized stakeholders throughout these monitoring-and-feedback cycles is crucial to New Governance's ability to impose accountability on more established actors, just as such participation is crucial to the initial problemsolving stage.

Inclusiveness, decentralized problem solving, and learning-by-doing are some of the characteristics that distinguish the model's "deliberateness" from mere "informal political, democratic, or majoritarian decision mak-

74 Brook. L. Riv. 275, 317-18 (2009) [hereinafter Bach, Welfare Reform]; Lisa Blomgren Bingham, Collaborative Governance: Emerging Practices and the Incomplete Legal Framework for Public and Stakeholder Voice, 2009 J. DisP. RESOL. 269, 307-08 (arguing that "public voice, not only in the form of interest groups and stakeholders, but also through direct civic engagement of citizens and residents, can address emerging concerns about accountability and legitimacy in the New Governance through enhanced transparency").

${ }^{23}$ Concerns about accountability and regulatory capture are just as high, if not higher, in New Governance as in other forms of governance. See, e.g., Ford, supra note 3, at 477; Jody Freeman, Collaborative Governance in the Administrative State, 45 UCLA L. REV. 1, 83 (1997) ("Some critics worry that collaborative processes might be vehicles through which agencies, industry, and powerful public interest groups can collude to undermine the public interest. Rather than provide an alternative to interest representation, these processes might exacerbate all of its weaknesses."); Kimberly D. Krawiec, Cosmetic Compliance and the Failure of Negotiated Governance, 81 WASH. U. L.Q. 487, 542 (2003) (stating that where law is incomplete, there is a "political opportunity for those with a stake in regulation to push their agenda through renegotiation during the implementation and enforcement phases of governance by constructing a gap-filling interpretation that serves the group's self-interest"); Super, supra note 5, at 541; Robert F. Weber, New Governance, Financial Regulation, and Challenges to Legitimacy: The Example of the Internal Models Approach to Capital Adequacy Regulation, 62 Adumin. L. Rev. 783, 850-55 (2010).

${ }^{24}$ See generally, e.g., Ford, supra note 3 , at 484 (describing "continuous self-assessment" in the field of securities regulation as including "iterative, multi-round stress tests; continuously shifting countercyclical capital reserve requirements; and continuous validation of riskassessment models"); Lobel, supra note 6, at 355. But see Super, supra note 5, at 556 (discussing the difficulty in defining reliable metrics).

${ }^{25} \mathrm{Cf}$. Ford, supra note 3, at 483-85.

${ }^{26}$ See Sabel \& Simon, supra note 6 , at $80-81$.

${ }^{27}$ Bach, Governance, supra note 22, at 241. 
ing." 28 Real-world practices, however, implement the theoretical model with varying degrees of thoroughness, in part because New Governance scholarship has largely followed the movement as it has unfolded in the world, extrapolating its theoretical principles in a post-hoc manner. ${ }^{29}$

Regardless, New Governance principles have "visibly influenced a broad range of critical policy initiatives in the United States and abroad."30 The New Governance approach is used by the courts, embedded in legislation, employed by administrative agencies, and promoted by both for-profit and nonprofit firms. Courts, for example, frequently ask litigants to negotiate their own remedies in a wide variety of cases, ranging from employment discrimination to securities regulation. The Occupational Safety \& Health Administration (OSHA) emphasizes decentralized problem solving by stakeholders in urging unions and employers to design better workplace safety procedures, rather than issuing top-down rules designed by bureaucrats. ${ }^{31}$ Some federal agencies use the Negotiated Rulemaking Act to draft proposed regulations through direct engagement with industry actors and consumer groups, rather than following traditional, top-down notice-and-comment procedures. ${ }^{32}$

Non-governmental organizations can also play leading roles in using New Governance techniques to instigate or accelerate reform efforts. Katherine Kruse, for example, discusses how the Wisconsin Innocence Project spearheaded wrongful-conviction reform by taking on a leadership role in legislatively supported New Governance procedures. ${ }^{33}$ The Brennan Center for Justice at the New York University School of Law encourages the use of a New Governance approach to generate construction jobs for local residents from real-estate-development projects. ${ }^{34}$ Countless other examples of $\mathrm{New}$ Governance-style approaches exist. ${ }^{35}$

${ }^{28}$ Douglas Nejaime, When New Governance Fails, 70 Оно Sт. L.J. 323, 336 (2009).

${ }^{29}$ Lester M. Salamon, The New Governance and the Tools of Public Action: An Introduction, 28 Fordham URb. L.J. 1611, 1621 (2000) (arguing that New Governance helps us to comprehend and manage what has already happened to government).

${ }^{30}$ Sabel \& Simon, supra note 6 , at 53 .

31 See Lobel, supra note 6, at 418-19.

${ }^{32}$ See, e.g., Cary Coglianese, Assessing Consensus: The Promise and Performance of Negotiated Rulemaking, 46 DukE L.J. 1255 (1997).

${ }^{33}$ Katherine R. Kruse, Instituting Innocence Reform: Wisconsin's New Governance Experiment, 2006 WIS. L. RIV. 645 (2006).

34 See Kate: Rubin \& Dougi Statis, Brinnan Ctr. ror Justict at NYU Sch. of Law,

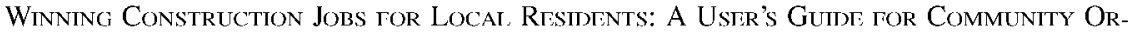
GANIZING CAMPAIGNS 16, 35 (2005), available at http://policyarchive.org/handle/10207/bit streams/8709.pdf (steps include to "[c]reate formal alliances with stakeholders" and "[g]et a respected seat at the table," negotiate for conditions that support local jobs, implement the program, and "monitor outcomes and adjust practices").

35 Other examples include the Participatory Budgeting Project, which helps public and private institutions to develop New Governance procedures "in which local people directly decide how to spend part of a public budget" in order to "empower community members to make informed, democratic, and fair decisions about public spending and revenue." Mission \& Approach, PARTICIPATORY BuDgEIING PrOIECT, http://www.participatorybudgeting.org/ who-we-are/mission-approach/ (last visited May 24, 2013). Another example is a private consulting company, which offers to help private- and public-sector clients "discover better ways 
In its ideal form, New Governance offers a number of potential benefits, many of which might seem especially appealing to those engaged in antipoverty efforts. The model supports the development of holistic, creative, cross-disciplinary, cross-jurisdictional, and cross-institutional solutions, which seem necessary to address complex problems like poverty ${ }^{36}$ and economic development. ${ }^{37}$ New Governance theory also supports greater access to decision-making processes by marginalized groups, promoting their ability to influence law and policy and to help reform social-welfare programs to better respond to their needs.

The model further suggests that participation by marginalized stakeholders may be a partial answer to the need for greater accountability of institutions responsible for administering policy and programs affecting the poor. Such accountability is a long-standing concern among antipoverty scholars that is heightened by the diffusion of responsibility for traditionally public services through privatization. ${ }^{38}$

In addition, the New Governance approach offers an avenue for socialjustice reform that is unconstrained by the procedural and substantive hurdles of litigation. ${ }^{39}$ It also offers reform-oriented organizations a structured framework through which they can promote social-justice initiatives rather than relying on administrative bureaucracies and other traditional authorities to take the lead.

On the other hand, the New Governance approach has some clear limitations. ${ }^{40}$ Practically speaking, it incurs high implementation costs. ${ }^{41}$ Signif-

to solve social problems" by designing collaborations across sectors, engaging stakeholders, and setting up evaluation procedures. Our Approach to Impact, FSG, http://www.fsg.org/Our Approach/Overview.aspx (last visited May 24, 2013).

${ }^{36}$ See Sabel \& Simon, supra note 6 . The need to better coordinate among antipoverty programs is also a long-standing one. See, e.g., Susan Bennett, The Threat of the Wandering Poor: Welfare Parochialism and Its Impact on the Use of Housing Mobility as an Anti-Poverty Strategy, 22 Fогрнлм Uкв. L.J. 1207, 1208 (1995) (discussing the conflicting goals between two key antipoverty strategies, income maintenance and assisted housing).

${ }^{37}$ See Bingham, supra note 22, at 273-74 ("So-called 'wicked problems' such as environmental degradation, urban economic development, and public health all challenged the capacity of a single governmental unit operating in hierarchy. . . This gave rise to the concept of governance, rather than government."); Sabel \& Simon, supra note 6, at 89.

${ }^{38}$ For a discussion of the need for additional accountability in privatized welfare services, see Michele Estrin Gilman, Legal Accountability in an Era of Privatized Welfare, 89 CALIF. L. Rrv. 569 (2001).

39 Michael Waterstone, A New Vision of Public Enforcement, 92 MinN. L. REv. 434, 438-39, 479 (2007) (describing a "strong consensus" among progressive scholars that many civil rights statutes "have not created as much social change as was originally hoped" and suggesting that New Governance "may ultimately challenge the assumption that litigation is the enforcement apparatus of choice.").

${ }^{40}$ For a comprehensive critique, see Super, supra note 5 (arguing that democratic experimentalism makes six unfounded assumptions: that participants will agree on the problem and on government's role in solving it, are "inclined to act in a public-spirited way" to solve the problem, and will agree on reliable metrics for assessment; that time and transaction costs are not significant barriers to participation; and that national regulation is unnecessary).

${ }^{41}$ See Avery Katz, The Strategic Structure of Offer and Acceptance: Game Theory and the Law of Contract Formation, 89 MicH. L. Rev. 215, 226-27 (1990) (explaining that implementation costs are "the concrete costs of undertaking specific activities and are in principle directly measurable," as opposed to "strategic behavior costs," which are "losses suffered 
icant investments of time, funding, expertise, and effort are necessary to support the robust participation by all stakeholders ${ }^{42}$ and to implement learning-by-doing procedures. ${ }^{43}$ Even assuming that these elements are in place, grave concerns remain. One of the most serious concerns is that the New Governance model relies on the meaningful participation of marginalized stakeholders to improve outcomes and provide accountability, but has not articulated a theory of how to promote such participation in the face of significant barriers. ${ }^{44}$

\section{B. The Problem of Cosmetic Participation}

"Meaningful participation" exists when the input provided significantly influences the outcome..$^{45}$ While it is impossible to articulate the exact point at which participation becomes "meaningful," Sherry Arnstein conceived of a continuum that expressed different levels of influence that citizens might have through participatory processes..$^{46}$

At the "high" end of Arnstein's continuum, marginalized groups have control over decisions. ${ }^{47}$ In the "middle" of the spectrum, they merely provide input and consultation without any assurance of influence over the outcome, which Arnstein describes as "tokenistic" participation. ${ }^{48}$ In between these two is what Arnstein describes as a "[p]artnership that enables [citizens] to negotiate and engage in trade-offs with traditional power holders." 49

The New Governance model essentially provides for this in-between form of participation by providing a structure through which marginalized stakeholders can negotiate with more powerful actors. Where negotiating power among stakeholders is dramatically unequal, however, the concern is that the negotiations process will produce only tokenistic participation, since

because bargainers have the incentive to maximize their individual gains rather than the total surplus from exchange").

${ }^{42}$ Robust participation requires that all relevant stakeholders are identified, that their input is solicited, and that they offer sufficient input. But for many reasons, some of which are discussed infra in Part III, participation by poor people and other marginalized stakeholders in New Governance processes may be low. This article acknowledges both the difficulties and importance of ensuring robust participation by marginalized stakeholders, but does not specifically address those issues. Rather, it generally assumes the existence of robust participation and focuses primarily on how to make that participation meaningful.

${ }^{43}$ See Super, supra note 5, at 554-616.

${ }^{44}$ Nejaime, supra note 28 , at 363 ("New Governance relies on a model of participation but has yet to elaborate ways for traditional outsiders to participate meaningfully in collaborative governance regimes.").

${ }^{45}$ Audrey G. McFarlane, When Inclusion Leads to Exclusion: The Uncharted Terrain of Community Participation in Economy Development, 66 Brook L. Rev. 861, 922 (2001),

${ }^{46}$ See Sherry R. Arnstein, A Ladder of Participation, 35 J. Am. Inst. Planners 216, 217 (1969). For a discussion of other frameworks for participation, see Bingham, supra note 22, at 291-92.

47 Arnstein, supra note 46, at 217.

${ }^{48} \mathrm{Id}$.

${ }^{49} \mathrm{Id}$. 
the input of less powerful actors will be solicited, but with no assurance or likelihood that their input will influence the outcome..$^{50}$

When the input of marginalized stakeholders is solicited but does not influence the outcome, the participatory process is a merely cosmetic one. It provides a "thin veneer of symbolic conformance" with participatory-governance principles, yet participants remain "unlikely to shift . . . existing dominant culture or norms of practice." 51

By definition, a cosmetic process invariably favors those already in power. ${ }^{52}$ Cosmetic processes not only fail to achieve good-governance aims, but affirmatively subvert them by "reinscrib[ing] existing power dynamics, allowing the "haves' to come out ahead" 53 and producing "a vicious cycle ... tilting more and more entitlements in favor of those already in power." 54

Cosmetic processes can occur when participants have good intent, but can also result from deliberate abuse. When diverse viewpoints are purportedly invited but without intent to incorporate them into the outcome, a participatory process merely becomes a means of legitimizing a preordained agenda. ${ }^{55}$ Powerful parties can thus use cosmetic processes to simply promote selfish interests, while giving the appearance that the outcome was vetted by and supported by a broad range of stakeholders.

The risk that a participatory process will be merely cosmetic rises when poor people are involved, as they face particularly high barriers to meaningful participation. As Wendy Bach explains, "the history of subordination and disproportionate power that characterizes social welfare history raises serious questions about the ability of poor communities to participate effectively" in New Governance systems. ${ }^{56}$ The perspectives of poor people may be disregarded due to factors such as race, culture, income, and language; a lack of traditional markers of expertise such as educational or professional credentials; and a lack of other resources that provide influence and bargaining advantages. ${ }^{57}$

\footnotetext{
${ }^{50}$ See Nejaime, supra note 28 , at 362 (" $[\mathrm{P}]$ articipatory structures may rhetorically include disempowered stakeholders but actually cede little or no power.").

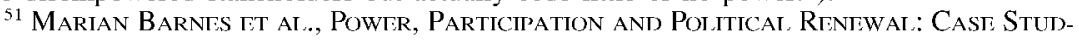
ies and Public Participation 192 (2007).

${ }^{52}$ See generally Nejaime, supra note 28, at 347-63 (discussing how New Governance process might favor those in power).

${ }^{53} \mathrm{Id}$. at 359.

${ }^{54}$ Lobel, supra note 6, at 458.

55 See BARNIS IT AI., supra note 51, at 192 (discussing "coercive isomorphism" and the likelihood that institutions may "go through the motions of public participation and involvement because they are likely to be judged on their record of doing so"); Susan D. Carle, Progressive Lawyering in Politically Depressing Times: Can New Models for Institutional Self-Reform Achieve More Effective Structural Change?, 30 HARV. J.L. \& GiNDIR 323, 337-38 (2007); Nejaime, supra note 28, at 360 ("[New Governance] may offer a way to legitimate the insider group's agenda."); Super, supra note 5, at 556.

${ }^{56}$ Bach, Welfare Reform, supra note 22, at 277.

${ }^{57}$ See Charles F. Sabel \& William H. Simon, Destabilization Rights: How Public Law Litigation Succeeds, 117 HaRv. L. Rгv. 1015, 1100 (2004) (discussing how "the dynamics of unequal bargaining power" affect negotiations).
} 
The harms of cosmetic processes are also multiplied when stakeholders are poor. Engaging in a New Governance system diverts scarce resources from other avenues of social-justice reform, and might even foreclose opportunities to challenge cosmetic outcomes. ${ }^{58}$ Furthermore, unfulfilled promises of empowerment and participation ${ }^{59}$ are likely to lead to further distrust and only deepen the community's marginalization.

Past experiments in participatory governance involving poor people indicate the challenges at hand. Scholars point to the disappointing results of the Johnson Administration's War on Poverty, which gave poor people "maximum feasible participation" rights in federally funded antipoverty initiatives, but did not produce the kind of meaningful, sustained influence by poor people over antipoverty programs that many had hoped for. ${ }^{60}$ Another familiar example is that zoning law generally provides for local stakeholder participation through mechanisms like open-meeting laws and citizen advisory panels, yet poor neighborhoods have overwhelmingly been sacrificed to make way for urban renewal and gentrification projects. ${ }^{61}$

That poor people have struggled to make a meaningful impact through participatory processes is not surprising, given that these processes ambitiously rely on groups with little power to successfully challenge entrenched interests and institutions using only a negotiations framework that does not correct for power imbalances. ${ }^{62}$ New Governance envisions that participants with power will alter dominant norms and practice based on the input of those traditionally holding little or no influence. It asks powerful actors to share their power with marginalized groups, to overcome cognitive and other

\footnotetext{
${ }^{58}$ Nejaime, supra note 28 , at 363 (arguing that cause lawyers might not participate in New Governance schemes out of concern that they cannot litigate the outcome if they have participated in the process).

${ }^{59}$ See Grainne de Burca, New Governance and Experimentalism: An Introduction, 2010 WIs. L. REV. 227, 236 (arguing that "the democratic promise of New Governance is hollow"); Joel Handler et al., A Roundtable on New Legal Realism, Microanalysis of Institutions, and the New Governance: Exploring Convergences and Differences, 2005 WIs. L. Riv. 479, 510 (describing cosmetic processes as a "charade" and "cruel").

${ }^{60}$ See Wendy A. Bach, Mobilization and Poverty Law: Searching for Participatory Democracy Amid the Ashes of the War on Poverty, 20 VA. J. Soc. Por'y \& L. 96, 102 (2012) ("[The War on Poverty] did not fully live up to its framers' vision, [but] it did have a significant effect on the ability of communities to direct resources to their needs and to build organizations and develop political leaders."); Super, supra note 5, at 570-74; see also Melish, supra note 19, at 17-18 ("[The War on Poverty's] legacy continues to haunt current national debates on social welfare policy and poverty alleviation").

${ }^{61}$ See, e.g., Barbara L. Bezdek, To Attain "The Just Rewards of So Much Struggle": Local-Resident Equity Participation in Urban Revitalization, 35 HOFsTRА L. Rev. 37, 55 (2006) (stating that in matters of urban development, participatory structures are inaccessible to poor residents); Patience A. Crowder, More Than Merely Incidental: Third-Party Beneficiary Rights in Urban Redevelopment Contracts, 17 GeO. J. ON Poverty L. \& POL'Y 287, 296 (2010); McFarlane, supra note 45 , at 869.

${ }^{62}$ See Amy J. Cohen, Negotiation, Meet New Governance: Interests, Skills, and Selves, 33 LAw \& SOC. INQUiRy 503, 530 (2008) (book review) (critiquing New Governance scholars' "faith . . . in the potential for new negotiated configurations of individual and collective interests to neutralize entrenched power hierarchies").
} 
biases that protect the status quo, ${ }^{63}$ and to sacrifice selfish interests in favor of policies that benefit less powerful groups or some notion of the "public good." $" 64$

For these reasons and others, there is good reason to wonder whether participatory processes can produce significant change for poor people. Many consider participatory processes to be substantially less effective in effecting reform than adversarial, rights-claiming techniques, ${ }^{65}$ and furthermore view them as carrying too high a risk of co-optation and acquiescence. ${ }^{66}$ Given the range of reasons to reject participatory processes as a means of social-justice reform, it is not surprising that many scholars and advocates question the relevance of the New Governance movement.

Regardless, the New Governance approach demands attention. The divergent visions of the New Governance model require explanation, and if meaningful participation can be better promoted, the model may offer a productive avenue for reform. Various case studies provide quantitative indications of improved outcomes. ${ }^{67}$ Further, whether one believes that New

${ }^{63}$ See Sabel \& Simon, supra note 57, at 1075-76 ("[E]mpirical psychology emphasizes that there are powerful cognitive tendencies toward entrenchment of the status quo.").

${ }^{64}$ See Saule T. Omarova, Rethinking the Future of Self-Regulation in the Financial Industry, 35 BROOK. J. INT' L. 665, 701-03 (2010) ("Of course, it may be argued that it is naïve to expect self-interested private parties to impose voluntary limitations on their own profit-seeking activities for the sake of the highly diffused and indeterminate public benefits."); see also McFarlane, supra note 45, at 926 ("[I]f we apply Arnstein's logic today, what she seems to be saying is that participation inevitably leads to either a shift in power or to exclusion. And exclusion is more likely a natural or inevitable result because a shift in power so clearly threatens to disrupt an otherwise settled, and often privatized, process.").

${ }^{65}$ See Jason M. Solomon, Law and Governance in the 21st Century Regulatory State, 86 TEx. L. Rev. 819, 850 (2008) (reviewing LAW AND NEW GovernANCE IN THE EU AND THE US (Gráinne de Búrca \& Joanne Scott eds., 2006) and Lisı Hein/erling \& M^rk V. Tushnet, The Regulatory and Administrative State: Maierials, Cases, Commenis (2006)) (" $[\mathrm{I}] \mathrm{f}$ the new governance scholars are going to succeed in understanding the circumstances in which such schemes will work, they must . . . account for the United States' culture of adversarial legalism, where interests represented by lawyers clash, and lawyers use and attempt to shape the law to serve their clients' interests. For better or worse, these lawyers are generally not trying to work with others to reach the 'best' social outcome ... . Rather, they are trying to advance their clients' interests in particular contexts.").

${ }^{66}$ See Scott L. Cummings, Mobilization Lawyering: Community Economic Development in the Figueroa Corridor, in Caust Lawyiass and Soctat. Moviemints 302, 303 (Austin Sarat \& Stuart A. Scheingold eds., 2006) (arguing that collaborative negotiation models may lead to quiescence); Freeman, supra note 23 , at 84-85 ("[P] roviding access to groups who define themselves in terms of their outsider status might undermine their role as critics of the system. Some organizations will view the participation and responsibility that collaboration portends as ultimately disempowering.").

${ }^{67}$ Success can sometimes be measured empirically. See Lobel, supra note 6, at 418-19 (citing workplace safety studies reporting an almost fifty percent reduction in incidents where New Governance methods were used); Susan Sturm, The Architecture of Inclusion: Advancing Workplace Equity in Higher Education, 29 HARv. J.L. \& GendER 247, 286-87 (2006) (describing quantitative and qualitative indicators of increased opportunities for the professional advancement of women in the sciences as a result of New Governance process). In other cases, success may be implied by the fact that the process produced substantive reforms, or measured through studies focusing on the participation rates and satisfaction levels of marginalized groups. See, e.g., Dorf \& Sabel, supra note 1, at 330-31 (noting that data from a 1995 community-policing initiative suggested that resident participation was highest among 
Governance can improve outcomes or not, it remains that the New Governance approach is being widely implemented, and often in ways that are highly susceptible to abuse. One scholar writes of a contemporary "participation industry," a "proliferation of efforts by government, nongovernmental organizations, private sector businesses, and intergovernmental bodies to ensure" voice, stakeholder participation, inclusion, and self-help that have largely been "discredited as mere tokenism." 68 Given the consequences of cosmetic processes, there is a need to further study the causes of cosmetic processes and to articulate a framework for better promoting meaningful participation.

\section{A Framework for Promoting Meaningful Participation}

To identify a theoretical framework for meaningful participation, it is helpful to first examine how existing New Governance theory addresses the matter. The following discussion suggests that the model can better protect against subversion and abuse if supplemented with a conceptual framework for providing stronger structural encouragement of meaningful participation. It locates a useful analogy in business transactions, articulating two baseline conditions that make it possible for business transactions to take place. These same conditions are shown to be relevant to court-based New Governance systems, which seek to establish these conditions as a means of structurally promoting meaningful participation by marginalized parties.

\section{A. The Model's Approach to Meaningful Participation}

The New Governance model predicts that diverse participation will surface conflict among stakeholders' competing interests, priorities, and points of view. To resolve this conflict, the model envisions stakeholders as engaging in deliberative processes.

Deliberative processes are rooted in Deweyan philosophy, ${ }^{69}$ "a venerable, recently revived tradition of politics [holding] that justifying one's position by giving reasons and responding to reasoned arguments for competing views can alter a person's understanding of her factual circumstances and her interests, disclosing previously unseen opportunities."

poor people and that participants felt that sixty-four percent of problems raised were being addressed).

${ }^{68}$ Melish, supra note 19 , at 91 .

${ }^{69}$ See William H. Simon, Solving Problems vs. Claiming Rights: The Pragmatist Challenge to Legal Liberalism, 46 WM. \& MAry L. Rev. 127, 131 (2004).

${ }^{70}$ Sabel \& Simon, supra note 57, at 1076. Dorf and Sabel offer an eloquent vision of how this might occur:

[W] orkable, long-term collaboration can issue from, and aid the construction of, the institution of problem-solving deliberation itself. Facing urgent problems that none can solve alone and seeking methods of establishing joint accountability, parties will often prefer to explore a potential solution, even if they are unsure of its outcome, than to do nothing. ... Once begun, pragmatic problem solving loosens the hold of 
deliberative process involves reasoned contestation, which is meant to move participants toward developing a resolution "approximat[ing] a common interest." 71

Ideally, under the model, deliberative processes lead to consensus by all stakeholders. Consensus does not guarantee that meaningful participation has occurred, especially when stakeholders with little negotiating power face those with significantly greater power. However, if consensus were required before participants could move forward with any proposed resolution, it would at least provide strong structural support for meaningful participation by all stakeholders, since it would provide even unempowered stakeholders with the ability to veto outcomes that inadequately incorporate their views.

Deliberative processes and a mandate to arrive at consensus are, however, difficult to carry out. Simon and Sabel note that "[i]n practice, the extent to which deliberation occurs . . varies"72 and that for deliberations to succeed, "parties have to be capable of . . treating each other with respect and remaining open to learning. Clearly, these conditions are not satisfied invariably." 73 Simon further recognizes the difficulty of inducing participants to transcend distributive bargaining ${ }^{74}$ and other theorists similarly acknowledge that it is generally infeasible to expect consensus. ${ }^{75}$ Consensus may be especially difficult to reach when marginalized stakeholders are involved, as their participation is in fact intended to generate contestation and challenge the status quo.

Consequently, the model does not mandate consensus, but rather emphasizes that participants should mightily strive toward consensus. ${ }^{76}$ Stakeholders who sincerely strive toward consensus will, by definition, work very hard to accommodate and incorporate each other's input into any proposed solution. ${ }^{77}$

However, the standard of striving toward consensus is extremely difficult to measure or enforce, and leaves open the door to cosmetic processes. For instance, participants can easily claim to strive toward consensus, while intentionally using the process to claim legitimacy for a preordained outcome. Even well-intentioned participants may produce a cosmetic outcome

interest by fitfully darting, as it were, beyond its reach, thereby discovering solutions bit by bit in the unfamiliar territory beyond the reach of bounded rationality and habitual calculations of advantage.

Dorf \& Sabel, supra note 1, at 321-22.

${ }^{71}$ Sabel \& Simon, supra note 57, at 1099.

${ }^{72} \mathrm{Id}$. at 1068 .

${ }^{73}$ See Simon, supra note 69, at 206-07.

${ }^{74}$ Id. at $208-09$.

75 Dorf \& Sabel, supra note 1, at 288-89 ("[E]xperimentalism does not pursue the chimera of replacing conflict with consensus.").

${ }^{76}$ Consensus is generally viewed as the ideal standard. See, e.g., Lobel, supra note 6, at 378 (arguing that negotiated rulemaking is "ideally" achieved through consensus building); $i d$. at 416 n.303 (noting that early OSHA New Governance processes "national consensus standards"); $i d$. at 438 (describing other New Governance decision-making processes as "primarily consensus based").

${ }^{77}$ See Sabel \& Simon, supra note 57, at 1068 ("[T]he consensus standard plays a valuable role even when no consensus is reached."). 
under this standard. When consensus is not reached, participants are still likely to feel pressure to produce a resolution, given the costs invested and likely publicity generated by a broadly inclusive participatory process. Under pressure to find a solution, participants may simply resort to a majority vote to break the deadlock ${ }^{78}$ or choose the resolution approved by the more powerful stakeholders. Either choice is likely to exclude marginalized stakeholders' interests from consideration.

If it is not feasible to mandate consensus and participants can only be asked to strive toward consensus, the risk of cosmetic processes is high. The aim, therefore, is to reduce this risk by seeking ways to encourage participants, through structural means, to strive toward defenses.

In seeking to articulate a framework for structurally encouraging participants to strive toward consensus, it is useful to consider other situations in which both conflict and consensus are presumed. While business transactions may seem an unlikely source of inspiration for matters of governance, in this limited respect they provide a useful analogy.

\section{B. Structural Encouragement in Business Transactions: The Baseline Conditions}

Business transactions, like New Governance, presume that conflict will exist yet that parties will strive toward consensus. When parties contemplate a business transaction, they expect that each party will have conflicting interests to be negotiated but also that each will strive toward consensus on the business terms, since the business transaction will not move forward without it. What motivates business partners to strive toward consensus and overcome conflict?

Two conditions motivate those contemplating business transactions. First, the parties are each motivated toward a common goal. Second, each party recognizes what the other party contributes toward that goal. These two baseline conditions propel the parties to sincerely strive toward consensus as they negotiate the terms of their business deal.

A simple example illustrates these baseline conditions. When a car owner and a car mechanic begin negotiating, each is motivated toward the common goal of exchanging car repair services for payment. The parties have different motivations (the mechanic wants income and the owner wants a car that works), and they expect some conflict (most obviously, one wants a higher payment and one wants a lower payment). However, they share a common goal of exchanging services for payment, which motivates them to overcome any potential conflicts and come to agreement.

The second baseline condition is that each party recognizes what the other party contributes toward the common goal. In the car repair context,

\footnotetext{
${ }^{78}$ See Dorf \& Sabel, supra note 1, at 320 (describing democratic experimentalism as deliberative in that "decisions regarding the provision of services are normally made by means of reason giving through discussion, not (except in cases of deadlock) the counting of votes").
} 
the contributions of each party are obvious: the owner contributes payment, and the mechanic contributes expert services.

Thus, this example illustrates that in business transactions, parties are motivated toward a common goal and recognize each other's contribution toward that goal. These conditions encourage the parties to sincerely strive toward consensus on the business terms.

Contracts scholarship supports this premise. One scholar explains that "contracts plainly present cases of "joint intentional activity." $\mathrm{Mel}$ Eisenberg notes that "[a] bargain promise requires and embodies two choices by the promisor. First, the promisor must choose to achieve a certain objective. Second, the promisor must choose to achieve or further that objective by making a given bargain" with another party. ${ }^{80}$ Similarly, James Henderson describes contract's "constitutive core" as the solving of problems by dealmaking: when parties attempt to solve a problem unilaterally, but realize that the solution "call[s] for the cooperation of other actors, the parties may engage in deal making to arrange for such mutual assistance." strive toward a contract, in other words, when each party understands its desire for a certain outcome, and recognizes that the other party can contribute toward that outcome. The two baseline conditions are thus the fundamental building blocks of business transactions.

It is worth noting that both baseline conditions must exist, for if either condition is lacking, the parties simply won't engage. If the parties aren't motivated toward a common goal-the owner wants a dent fixed, for example, and the mechanic only performs engine work-they see no point in working toward consensus. Parties who do not recognize the other party's contribution will also refuse to engage. A car owner will not negotiate terms of a lease with a mechanic who has a reputation for not doing a good job, for example.

It should also be understood that while the baseline conditions are necessary for the business deal to take place, they are certainly not sufficient to guarantee that it will. 82 The car owner and mechanic might be motivated to agree on a mutually satisfactory date for the work to be completed, for instance, but for logistical reasons, may fail to find one.

${ }^{79}$ Daniel Markovits, Contract and Collaboration, 113 YALE L.J. 1417, 1456-57 (2004).

${ }^{80}$ See Melvin A. Eisenberg, Mistake in Contract Law, 91 CAI IT. L. Rrv. 1573, 1581 (2003).

${ }^{81}$ See James A. Henderson, Jr., Contract's Constitutive Core: Solving Problems by Making Deals, 12 U. It.. L. Riv. 89, 94 (2012).

${ }_{82}$ This article focuses on the narrow question of the baseline, minimum, or threshold conditions. Thus, a "theory of bargaining" that "predicts under what circumstances bargainers will be able to reach a cooperative outcome" through a New Governance process is outside the scope of this paper. See Katz, supra note 41, at 227. For a discussion of New Governance and behavioral economics, see On Amir \& Orly Lobel, Stumble, Predict, Nudge: How Behavioral Economics Informs Law and Policy, 108 Corum. L. R5v. 2098, 2127-38 (2008) (reviewing Richard H. Thaler \& Cass R. Sunstein, Nudge: Improving Decisions About Henlth,

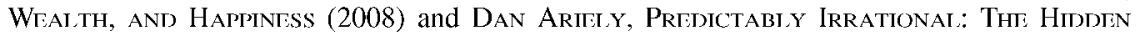
Forces That Shape Our Decisions (2008)). 
Other factors might also thwart ultimate agreement. Over time, changed circumstances and information may reduce motivations. The car owner may lose motivation to contract with the mechanic, for example, if a friend offers to fix the car for free. A mechanic might be motivated to accept a job at first, but later realize that it requires expertise she does not have.

Any number of explicit and implicit factors may affect even simple business decisions, such that even if the baseline conditions are in place to a certain degree, or at one point in time, the transaction may still ultimately fail to take place if motivations are not sufficiently strong or sustainable under changed circumstances. The baseline conditions are thus necessary, but not sufficient, to guarantee consensus on business terms.

Moreover, even if the parties do reach consensus on the business terms, this fact alone is not sufficient to guarantee that the parties' primary interests will in fact be met. The car owner may ask the mechanic to do minimal repairs because it is all she can afford, even though she would be much better off with a car that is safer and more reliable. Consensus may not mean that all parties are in fact satisfied, but rather may be born from necessary compromise..$^{83}$

Therefore, even when the baseline conditions are established, this does not guarantee either that consensus will be reached or that the participants' needs will be adequately met. Yet the conditions are important to articulate precisely because they are the minimum or baseline conditions required to motivate the participants to seriously consider each other's needs and interests. In other words, these conditions are necessary for all parties to have the chance at meaningfully participating in the business negotiations; if the conditions are not present, meaningful participation will fail.

Likewise, this article suggests that the same two baseline conditions must be in place before marginalized stakeholders can possibly participate meaningfully in New Governance processes.

The next section illustrates in more detail the relationship between the baseline conditions and New Governance systems. It discusses how courtbased systems promote the two baseline conditions to encourage meaningful participation in negotiations between marginalized plaintiffs and more powerful defendants.

\section{Structural Encouragement in Court-Based New Governance Systems}

In their seminal work, Destabilization Rights, William Simon and Charles Sabel analyzed lawsuits involving plaintiffs from archetypically marginalized groups. ${ }^{84}$ The plaintiffs in these cases included developmentally disabled individuals bringing claims against institutions charged with

\footnotetext{
${ }^{83}$ Even the achievement of consensus does not indicate that all stakeholders have meaningfully participated. See generally Cohen, supra note 62.

${ }^{84}$ Sabel \& Simon, supra note 57 , at 1021 .
} 
their daily care, prisoners suing prison officials, public-school students bringing discrimination suits against school systems, members of the public alleging police abuse, and public-housing residents and other low-income housing activists suing local government agencies. ${ }^{85}$

In these cases, the courts have tended toward an experimentalist approach that emphasizes litigants negotiating their own remedial plans, rather than issuing top-down, judicially fashioned remedies. ${ }^{86}$ This process actively promotes the same two baseline conditions needed for business transactions to move forward. In these court cases, the baseline conditions encourage the meaningful participation of marginalized plaintiffs in the design of the remedial plan.

The first baseline condition is that the parties must be motivated toward a common goal, just as the car owner and mechanic are both motivated to get the car fixed. In "destabilization" cases, however, the parties arrive in court precisely because they want different, mutually exclusive outcomes: each side has a starkly contrasting vision of the relationship between the defendant and the plaintiff. The liability finding in favor of the plaintiff, however, changes this. In Sabel and Simon's terms, the liability finding creates "destabilizing," $"$ "disentrenching," 88 or "unsettl[ing]" effects that "induce the [defendant] to reform itself in a process in which it must respond to previously excluded stakeholders." ${ }^{0}$ In other words, the liability finding radically changes the defendant's goal ${ }^{91}$ from one at odds with the plaintiff's goal to one consistent with it. The new goal shared by the parties is to agree upon a remedy that will gain approval by the court.

In addition to creating a shared goal where none previously existed, the court process also imposes strong motivations for the recalcitrant party to achieve this goal. The court could reject a proposed plan for inadequately reflecting the plaintiff's interests and instead impose a receivership or courtdefined remedial plan. As Simon and Sabel suggest, the uncertainty inherent in those alternatives strongly motivates the defendant to work toward consensus on the remedial plan. ${ }^{92}$

The second condition necessary to promote meaningful participation is that the participants recognize the value of the others' contributions to the common goal. In the context of business deals, a party easily recognizes how the other contributes to the business deal. In destabilization cases, the parties' arrival in court indicates that the defendant, in fact, little values the

${ }^{85}$ See id. at 1022, 1029, 1034, 1043, 1047.

${ }^{86} \mathrm{Id}$. at $1067-68$.

${ }^{87}$ Id. at 1055 (terminology attributed to Roberto MANGABeira Unger, FAlSe NeCes Sity: Antt-Nichssitarian Sociat. Thtory in the Strkvice or Radicai, Dimocracy 530 (1987)).

${ }^{88} \mathrm{Id}$. at $1074-82$.

${ }^{89} \mathrm{Id}$. at 1062 .

${ }^{90} \mathrm{Id}$. at 1056

91 "The court's principal contribution is to indicate publicly that the status quo is illegitimate and cannot continue." $I d$.

92 Sabel \& Simon, supra note 6, at 53. 
plaintiff's views. But again, the court process changes this. The liability finding gives credence to the plaintiff's views, and makes it patently obvious to the defendant that plaintiff's interests must be incorporated into the remedial plan.

While the court-based system promotes the two baseline conditions, the process of negotiating a remedial plan in these cases obviously remains fraught and difficult. The liability finding does not mean that the defendant adopts the plaintiff's interests as its own out of either newfound respect or concern for the plaintiff's position; it merely changes the defendant's selfinterest so that it is newly aligned with the plaintiff's interest. ${ }^{93}$ The baseline conditions thus do not erase antagonism or guarantee that consensus will be reached, that meaningful participation will occur, or that the marginalized party's concerns will be adequately addressed. ${ }^{94}$

Nevertheless, the baseline conditions remain critical to the integrity of the New Governance process. In other words, if the court process did not work to promote these baseline conditions, meaningful participation in these instances would surely fail. The support of the baseline conditions makes it at least possible for meaningful participation to succeed.

\section{Promoting Meaningful Participation Outside of the Courts}

If the baseline conditions necessary for business transactions are promoted by court-based New Governance systems, can those same conditions be promoted outside the courtroom? This question is important because outside the courtroom, New Governance-style systems abound, yet the risk of cosmetic processes is especially high.

In part, this is due to the fact that those promulgating New Governance systems outside the courtroom, such as legislatures, administrative agencies, and private organizations, lack the courts' extraordinary power to coerce participants into striving toward consensus. New Governance systems implemented outside the courtroom generally lack one central "architect" who wields coercive power over all participants, which may include a diverse array of public and private institutions as well as individuals and members of the public at large. Yet case studies suggest that at least under some circumstances, the New Governance model can be applied to create collective action by these diverse stakeholders to make change based in part on the input of traditionally marginalized and unempowered groups.

The baseline conditions provide a useful conceptual framework for understanding how meaningful participation can be promoted in New Govern-

\footnotetext{
${ }^{93}$ This is an example of interest convergence. See Derrick A. Bell, Jr., The Unintended Lessons in Brown v. Board of Education, 49 N.Y.L. SCH. L. Rev. 1053, 1056 (2005) ("The interest of blacks in achieving racial justice is accommodated only when and for so long as policymakers find that the interest of blacks converges with the political and economic interests of whites.").

${ }^{94}$ See discussion on baseline conditions supra Part III.B.
} 
ance systems taking place outside the courtroom. The following discussion draws on a variety of proposals intended to promote meaningful participation, and frames and analyzes these proposals according to how they support the baseline conditions. ${ }^{95}$ While this discussion is not exhaustive of all means of promoting meaningful participation, it conceptually categorizes the most prominent of these ideas, discusses their relevance to the baseline-conditions framework, and discusses certain of their limits and benefits. It then analyzes a few short case studies to demonstrate how some of these ideas have been applied, and draws some broader lessons about what may be necessary to prevent cosmetic processes and encourage meaningful participation outside of the courts.

\section{A. Promoting Baseline Condition One: Defining a Common Goal and Motivations Toward It}

There are three general means of promoting the first baseline condition, or motivation toward a common goal. As discussed below, participants can become motivated to work toward a common goal when a "destabilizing" event occurs. Participants might also define their own goals and motivations, if supported by mechanisms that elicit meaningful input and facilitate conflict resolution. The architect of a participatory process may also define the common goal, along with incentives for participants to achieve it.

\section{Destabilizing Event Creates a Common Goal and Motivations}

The defining characteristic of a destabilizing event is that it indicates to stakeholders that the status quo is no longer acceptable and that they must pursue change. ${ }^{96}$ In the lawsuits studied by Sabel and Simon, the liability finding served as the destabilizing event that defined a common goal shared by both defendant and plaintiff where no common goal previously existed. Outside the courtroom, other kinds of destabilizing incidents may serve the same purpose. In Cincinnati, for example, a series of tragic shootings and other tensions between police and residents culminated in three days of violent protests. Environmental calamities may have been instrumental in inspiring New Governance procedures to address natural-resources concerns. ${ }^{97}$ Destabilizing events can provide motivations to work toward a common goal, which is the first of the two baseline conditions necessary to spur par-

95 These proposals include ideas implemented in practice as well as scholarly prescriptions for future implementation, and are abstracted from sources analyzing both New Governance-style systems and the urban-development process, which is not a New Governance process but relevant in that it is a participatory system.

${ }_{96}$ See Sabel \& Simon, supra note 57, at 1074-82 (stating that one of the six effects of destabilizing litigation is that "the liability determination reverses the normal presumption in favor of the status quo").

${ }^{97}$ See Bradley C. Karkkainen, Getting to "Let's Talk": Legal and Natural Destabilizations and the Future of Regional Collaboration, 8 NEv. L.J. 811 (2008). 
ticipants to strive toward consensus. Destabilizing events, while often tragic, therefore can help to create fruitful opportunities for problem solving.

\section{Participants Define a Common Goal and Motivations}

The first baseline condition needed to promote meaningful participation, motivation toward a common goal, might also be promoted by enhancing the opportunities for marginalized stakeholders to provide input and engage with other stakeholders. Proposals for enhanced participation of stakeholders commonly include holding more public meetings, ${ }^{98}$ soliciting testimony by individual citizens on a massive scale, ${ }^{99}$ and using broad surveys or polls to gather input. ${ }^{100}$ Others include imposing heightened transparency measures, such as strong sunshine laws, ${ }^{101}$ and requiring that agendas, issues, and proposals be published for review and comment. ${ }^{102}$

This approach seeks to promote the definition of a common goal through enhanced participation procedures. The premise underlying this approach is that if stakeholders are well informed and given ample opportunities to participate, they will come to the table with more ideas and perspectives, engage with each other, and eventually be able to identify a common goal toward which all are motivated. This approach ultimately relies on participants engaging in deliberative processes to uncover common ground. However, deliberative processes are more likely to succeed if participants actively engage with each other rather than simply trade information. More promising approaches, therefore, include face-to-face meetings of small groups of participants to better foster two-way engagement and dia$\operatorname{logue}^{103}$ and the use of alternative-dispute-resolution systems to facilitate conflict resolution. ${ }^{104}$

${ }^{98}$ See Damon Y. Smith, Participatory Planning and Procedural Protections: The Case for Deeper Public Participation in Urban Redevelopment, 29 Sr. Louis U. Pub. L. Rev. 243, 262 (2009).

${ }_{99}$ See Melish, supra note 19, at 79 (describing the testimony of ten thousand individuals as part of South Africa's hearings on poverty).

${ }^{100}$ See, e.g., Simmons, supra note 1.

${ }^{101}$ See Patience A. Crowder, "Ain't No Sunshine": Examining Informality and State Open Meetings Acts as the Anti-Public Norm in Inner-City Redevelopment Deal Making, 74 TENN. L. Rev. 623 (2007). Proposals for transparency also support mobilization. See infra Part IV.B.2.

${ }^{102}$ See Bach, Governance, supra note 22, at 295; see also Chester L. Mirsky \& David Porter, Ambushing the Public: The Socio-Political and Legal Consequences of SEQRA Decision-Making, 6 Ais. L. Envti. Outlook J. 1 (2002).

${ }^{103}$ See Kruse, supra note 33, at 716; see also Elizabeth A. Kirk \& Kirsty L. Blackstock, Enhanced Decision Making: Balancing Public Participation Against "Better Regulation" in British Environmental Permitting Regimes, 23 J. ENVTT. L. 97, 109 (2011) ("With the best will in the world the regulator may fail to understand the significance of information or values presented to it through these processes and better understandings may only truly develop through processes involving dialogue between interested parties."); McFarlane, supra note 45, at 880-84 (discussing limitations of public hearings that provide only "one-way participation" yet are deemed legally sufficient).

${ }^{104}$ But see Cohen, supra note 62 , at 504 (raising challenges to the suggestion by "both negotiation and new governance theorists ... that individual interest-bearers, instilled with the 
For example, a city seeking ideas on how to best make use of a large downtown property recently vacated by a manufacturer might broadly solicit input from residents, business owners, educational leaders, city agencies, foundations, and others. Using the approach of encouraging participants to define their own goals, the city would offer ample opportunities for participation and two-way engagement, and conduct the process with transparency. The aspiration would be that through discussion and debate, these stakeholders will define a common goal or set of goals for the property.

The primary benefit of this approach is that participants come to their own definition of the goal, which is valued as local stakeholders have unique knowledge of the problem and of possible solutions and also of what might motivate them to work toward any particular goal. However, given that the deliberative state is so difficult to achieve, and given the level of conflict anticipated when marginalized stakeholders participate, substantial investments of time and other resources are likely to be necessary to facilitate participants' use of the deliberative process. Furthermore, such investments may still be insufficient to enable stakeholders to define common goals toward which they are all motivated.

\section{Architect Imposes a Common Goal}

A third possibility for promoting the first baseline condition, motivation toward a common goal, is for a New Governance architect to define the common goal for the participants along with motivations toward that goal. The primary benefit of this approach is that it can be used where participants cannot agree on a common goal.

For example, the California Legislature might pass a law mandating better occupational safety. The state agency tasked with carrying out this goal might in turn impose responsibility for this goal primarily on employers and unions. In this instance, by setting the goal of increased workplace safety, the legislature and the state agency together defined a common goal for employers and unions to work toward.

In employing this approach, architects must take care to avoid replication of a command-and-control structure and to promote decentralized problem solving driven by local stakeholders. Toward this end, architects should define "framework" goals only. ${ }^{105}$ A framework goal would ask participants to find ways to "increase workplace safety," for instance, rather than imposing specifically prescriptive actions such as "reduce hours worked and increase training." In other words, architects should refrain from defining specific methods of achieving the goals, and instead allow stakeholders to tailor solutions to local conditions. ${ }^{106}$ Architects should also define tentative

proper configuration of dialogic and problem-solving skills, can, through negotiation, combine their interests with the interests of others in ways that reconfigure extant power hierarchies"). ${ }^{105}$ Sabel \& Simon, supra note 6, at 79.

${ }^{106}$ See Ford, supra note 3, at 480 n.148 (distinguishing between promoting participation and prescribing specific outcomes). 
standards for assessment. This assists in setting expectations for what the participants should be striving toward, providing measures to hold participants accountable, and reducing the risk that the participants will undermine the substantive goal by setting only very weak assessment measures. ${ }^{107}$

\section{Architect Creates Motivations}

The first baseline condition is not only that a common goal must be defined, but that the parties must also be motivated to strive toward it. Motivation must be created when an architect imposes a common goal that isn't chosen by the participants themselves. Even when motivations surface through destabilizing events or through the participants' own definition of their goals, additional incentives to work hard to achieve the goal are likely necessary.

The need to establish motivation toward the goal is especially strong in systems taking place outside of the courtroom, where stakeholders are often not captive. Accordingly, proposals for creating incentives abound. Some of the more prominent motivators are soft motivators, "hybridity," and penalty defaults.

Soft motivators encourage the voluntary pursuit of the stated goal. Grant funding can be a potent soft motivator. So can the relaxation of regulatory oversight. When workplace-safety records improve through voluntary efforts, for example, OSHA releases employers from more invasive agency oversight. ${ }^{108}$

Other motivators may involve more coercive power. The theory of "hybridity" explored by David and Louise Trubek suggests that New Governance methods are especially effective when the goal toward which the parties are striving implicates "hard law" rights. ${ }^{109}$ Many New Governance case studies involve participatory processes that occurred in the shadow of litigation, where lawsuits had already been filed, as in Cincinnati, or where lawsuits had not yet been filed but conceivably might have been. Setting framework goals backed up by hard rights can thus motivate participants to work toward that goal.

${ }^{107}$ Sabel \& Simon, supra note 6, at 79. Assessment measures can reduce the risk of abuse. See Cameron Holley, Facilitating Monitoring, Subverting Self-Interest and Limiting Discretion: Learning From "New" Forms of Accountability in Practice, 35 Colum. J. EnviL. L. 127, 206-07 (2010) (arguing that where only general outcomes are specified, additional accountability mechanisms are required to thwart abuse).

${ }^{108}$ See Lobel, supra note 6, at 418.

${ }^{109}$ See David M. Trubek \& Louise G. Trubek, New Governance \& Legal Regulation: Complementarity, Rivalry, and Transformation, 13 Colum. J. Eur. L. 539, 541 (2007) (discussing "hybrid system[s] in which innovation, negotiation and self-monitoring are foregrounded, while regulatory enforcement remains in the background as a default option"); see also Arnold S. Rosenberg, Motivational Law, 56 Ci.rv. ST. L. Rгv. 111, 114 (2008) (discussing that "motivational law" can increase compliance with "regulatory" or hard law). For a discussion of the use of hard law in New Governance systems as too constricting of local discretion, see Lobel, supra note 6, at 382. 
"Penalty defaults" can also function as motivators. In the context of destabilization lawsuits, if litigants fail to agree on an appropriate remedial plan, the court can impose its own plan, a default so unappealing that it effectively penalizes participants failing to come to agreement on their own. ${ }^{110}$ Outside of the courtroom, environmental law provides an example: under the Endangered Species Act, if developers and environmental organizations fail to negotiate an agreement concerning a sensitive habitat, no development can occur in that area. ${ }^{111}$

In sum, the first baseline condition-motivation toward a common goal-can be established outside the courtroom in at least three ways: through a destabilizing event, through facilitated deliberation by the participants, and as imposed by an architect.

\section{B. Promoting Baseline Condition Two: Recognition of the Marginalized Stakeholder's Contributions}

The second baseline condition is that participants recognize the contribution of other participants toward achieving their common goal. This condition must exist, along with the first baseline condition, in order for meaningful participation to be possible.

In some situations, marginalized stakeholders offer expertise that is relatively easy for others to recognize. Factory-floor workers have obvious expertise in how their own workplace might be made safer. Patients can speak with authority on how to improve the experience of those under the care of a medical clinic.

In part, the contributions of the marginalized stakeholders in these situations are obvious because the goals-improving workplace-safety records and improving patient care-are defined with their interests in mind. When the goal is properly defined so as to be common to all stakeholders, the goal incorporates the interests of marginalized stakeholders, which in turn can raise the value of their input. A properly defined goal (part of the first baseline condition) can thus make it easier for others to recognize their contributions toward that goal (the second baseline condition).

As discussed supra in Part III, however, marginalized-stakeholder expertise is often contested. Intended beneficiaries of social-welfare programs, for example, are uniquely qualified to opine on how to make those programs more useful in meeting their needs, ${ }^{112}$ yet their voices are largely excluded from discussions about the design of antipoverty initiatives. ${ }^{113}$

There are at least three ways to encourage other participants to recognize the contributions of marginalized stakeholders where this recognition

${ }^{110}$ See Sabel \& Simon, supra note 57, at 1067.

${ }^{111}$ See Sabel \& Simon, supra note 6 , at 91.

112 See id. at 89.

113 See Bach, Governance, supra note 22, at 239 ("[T] tion by poor communities in goal-setting and program design fundamentally undermines the experimentalist enterprise."). 
does not otherwise exist: the use of proxies, mobilization or community organizing, and the definition of a specific weight to be afforded to the input of those stakeholders.

\section{Proxies}

New Governance case studies indicate a reliance on formal organizational representatives to stand in for direct participation by marginalized stakeholders. California's occupational safety agency, for example, relies on unions to represent workers. ${ }^{114}$ In the case of Wisconsin's innocence reform initiative, lawyers from the Innocence Project advocated on behalf of wrongfully convicted individuals. In practice, nonprofit organizations are often considered as representing the needs of poor individuals.

Proxies make New Governance processes more feasible by reducing the costs and other logistical challenges of soliciting direct participation. Furthermore, proxy representatives may already have stature at the bargaining table, holding educational and professional credentials valued by other participants. Nonprofits and organizations like unions also have legal structures suggesting that they represent stakeholder interests.

On the other hand, proxies lack the direct experience that stakeholders themselves offer and that the New Governance model so deeply values. Proxies may not adequately represent the stakeholders' interests, ${ }^{115}$ are susceptible to co-optation and acquiescence, and can be even "less inclusive and less broadly accountable" than the government. ${ }^{116}$

Given these limitations, reliance on the use of proxies in New Governance must be carefully considered. To compensate for the lack of direct stakeholder participation, funding or structural support can be provided to encourage proxies to engage directly with stakeholders and promote adequate representation of their interests. As a check on proxy representation, New Governance systems might also build in periodic consultation with the stakeholders directly, or solicit impact statements by stakeholders who object to the proxies' representation. ${ }^{117}$

\section{Mobilization}

Community organizing or mobilization is another means of persuading other participants to recognize a marginalized group's contribution. ${ }^{118}$ Since

114 See Lobel, supra note 6, at 418.

115 See Lisa T. Alexander, The Promise and Perils of "New Regionalist" Approaches to Sustainable Communities, 38 FordHam URb. L.J. 629, 657-58 (2011) ("[S]takeholder representatives, however, may not be as attentive to the concerns of grassroots or politically-activist stakeholders.").

116 Simon, supra note 69 , at 177.

${ }^{117}$ See Alexander, supra note 115, at 657-58 (discussing the use of proxies in the U.S. Department of Housing and Urban Development's Sustainable Communities program).

${ }^{118}$ The literature on mobilization is extensive. For discussions particularly relevant to this context, see Bach, Welfare Reform, supra note 22, at 316 (describing community-based grass- 
mobilization emphasizes giving voice to marginalized individuals themselves as representatives of their own communities, it is strongly preferred over the use of proxies, which raises significant concerns about co-optation, capture, or inauthentic representation.

Mobilization can combat skepticism about the group's credibility through the demonstration of numerosity. Numerosity is critical to credibility, since to be deemed legitimate contributors to a problem-solving process, marginalized individuals usually must demonstrate that they represent a collective perspective, rather than self-interested or opportunistic viewpoints. ${ }^{119}$

Mobilization, especially in large numbers, also indicates political power, which may persuade other participants to listen. It can draw attention to the issues and attract more well-established or well-resourced allies, further increasing the group's influence. ${ }^{120}$

New Governance architects seeking to promote meaningful participation might thus seek out circumstances in which mobilization has already occurred. New Governance architecture can also incorporate broader participation and transparency measures, as described in Part IV.A.2, which may support mobilization and larger turnouts of better-informed stakeholders.

More direct support for mobilization as a means of convincing participants of the value that marginalized stakeholders bring to the table would include funding and training for organizing efforts. ${ }^{121}$ Such support must also be accompanied by adequate time for mobilization to take root. ${ }^{122}$ Where marginalized groups are already organized or where an urgent call to

roots organizing as the "best hope for capturing and amplifying the opinions, needs, and goals of poor communities as well as exercising the power necessary to communicate and negotiate for these needs"); David Dominguez, Getting Beyond Yes to Collaborative Justice: The Role of Negotiation in Community Lawyering, 12 Gгo. J. ON Povirty L. \& Pol'y 55 (2005); Julissa Reynoso, Putting out Fires Before They Start: Community Organizing and Collaborative Governance in the Bronx, U.S.A., 24 LAW \& INTQ. J. 213 (2006); Bach, supra note 60, at 53.

${ }^{119}$ See Lisa T. Alexander, Stakeholder Participation in New Governance: Lessons From Chicago's Public Housing Reform Experiment, 16 Gro. J. on Poverty L. \& Por'y 117 (2009); see also Georgette C. Poindexter, Who Gets the Final No? Tenant Participation in Public Housing Redevelopment, 9 Corñt. J. J.L. \& Pub. Por'y 659 (2000).

${ }^{120}$ Mobilization, especially that undertaken in the style proposed by Saul Alinsky, is not undertaken with the purpose of collaboratively working toward a common goal, but as a means of contestation. For this reason, mobilization may seem a poor fit for New Governance, which is frequently described as a "collaborative" process. Ideally, however, contestation within a New Governance system leads to a changing of the goal to one that better meets the interest of all stakeholders. See also Lobel, supra note 6, at 461 n.547.

${ }^{121}$ See Simon, supra note 69, at 208 ("Another alternative intervention would be to strengthen weaker parties directly, say, by transferring resources organizing assistance."); Alastair R. Lucas, Canadian Participatory Rights in Energy Resource Development: The Bridges to Empowerment?, 24 J. LAND Resources \& ENvIL. L. 195, 199 (2004).

${ }^{122}$ See Mariana Hernandez Crespo, Building the Latin America We Want: Supplementing Representative Democracies With Consensus-Building, 10 CaRdozo J. ConII ICT Rгsot. 425, 490 (2009) (citing the "difficulties of organizing a representative and accountable citizens" group in the face of futility, alienation, and distrust."); see also Cohen, supra note 62, at 544 ("[Some New Governance critics"] participatory projects appear driven by the conviction that the interests of excluded populations must be sufficiently politicized through (if necessary, contentious) collective action before they can become subject to legal/problem-solving processes."). 
action is possible, the mobilization process may be relatively quick, but in many situations, effective mobilization may take significant time.

Before relying on mobilization as a primary means of promoting recognition of marginalized groups' contributions, it must be carefully considered whether organizing has already taken root within that community, whether additional efforts are supportable through funding and training, and whether there is sufficient time for effective organizing to take place before the participatory process begins.

\section{Architect Affords Certain Weight to Participants' Input}

A third means of recognizing marginalized stakeholders' contributions is the use of rules that afford a specific measure of weight to their input.

A potent version of this concept would require consensus by all stakeholders on key decision points. ${ }^{123}$ Its strongest expression would place decision-making power in the hands of marginalized groups. While either mandating consensus or giving control to marginalized groups may seem unlikely, in some cases these may be options. For example, patients hold the majority of board seats of federally funded community health centers. ${ }^{124}$ Similarly, community-controlled groups might be given the right to monitor how well private contractors administer social-welfare programs. ${ }^{125}$

If such options are not available, however, a New Governance system may include weaker versions of this proposal. It may mandate, for example, that the input of marginalized stakeholders must "materially impact" a decision, ${ }^{126}$ or require that outsider input be afforded "great weight." ${ }^{27}$ Proposals along these lines often include exceptions for "feasibility"128 or are otherwise difficult to enforce. To be effective in promoting the recognition of marginalized groups' contributions, the abuse of such standards must be discouraged by drawing any exceptions narrowly, imposing a high burden of proof to show both that the standard is met and that any exception is warranted, and carefully scrutinizing claims for exceptions.

\section{Illustrations}

The preceding sections discuss various ways in which the two baseline conditions may be established outside the courtroom in order to promote

\footnotetext{
${ }^{123}$ But see supra Part III.A (noting that consensus does not guarantee meaningful participation).

${ }^{124}$ See Campbell, supra note 2, at 398.

${ }^{125}$ See Bach, Governance, supra note 22, at 294, 317-18 (suggesting that "communitycontrolled monitoring bodies" may increase the accountability of privatized welfare services); Bach, Welfare Reform, supra note 22, at 317-24.

${ }_{126}$ Smith, supra note 98 , at 262.

127 See, e.g., Office of Zoning, Gov'l of D.C., Zoning in The District of Columbia (2011) (requiring the Board of Zoning Appeals to give "great weight" to the opinion of Advisory Neighborhood Councils, which are made up of community members, as to whether certain exceptions to the zoning law should be permitted in any particular case).

${ }^{128}$ See Smith, supra note 98 , at 262.
} 
meaningful participation by marginalized stakeholders. ${ }^{129}$ This section illustrates how such proposals have played out in particular factual contexts.

The first example returns to Cincinnati's police-reform initiative, in which each of the baseline conditions was promoted in multiple different ways. The first baseline condition, motivation toward a common goal, was established through a combination of destabilizing events, hybridity, penalty defaults, and architect-imposed goals.

Three days of violent protests acted as a destabilizing event that propelled stakeholders to understand that they shared a common goal of preventing further violence on the part of both the police and African American protestors. This destabilizing event also perhaps functioned as a penalty default, motivating participants to find a solution in order to avoid further protests and police shootings.

Hybridity was also at work in Cincinnati. The New Governance process took place in the shadow of litigation filed on behalf of marginalized stakeholders. A "framework goal" of preventing the abuse of police power ${ }^{130}$ had already been established by a federal statute prohibiting unlawful police patterns or practices, ${ }^{131}$ which may have further encouraged participants to move toward that goal. It is likely that the possibility of litigation served in Cincinnati as a "penalty default."

The second baseline condition, the recognition of the contributions of the marginalized participants, was also established through various means. The marginalized stakeholders, African American residents, were clearly instrumental to the common goal of ending the violence. The residents also gained recognition through the use of mass participation methods, like the surveys. Meetings with small groups of stakeholders also likely helped to legitimize the residents' positions and provide dialogue. ${ }^{132}$

Proxies also played a significant role. African American residents were represented by the United Black Front and the American Civil Liberties Union of Ohio Foundation, which had brought suit as formal representatives of the class and continued to play pivotal roles as proxies during the negotiations. ${ }^{133}$

In addition, while these negotiations were voluntary pretrial negotiations, not mandated by a liability finding, the backdrop of the litigation afforded the proxies a specific amount of weight in the decision making, since their approval was necessary in order to settle the litigation. All of these approaches served to legitimize the contribution of the marginalized stakeholders.

${ }^{129}$ Appendix 1 provides a summary in table form.

${ }^{130}$ While the federal statute itself does not conform to New Governance principles, see Simmons, supra note 1, at 416-18, that is immaterial to this discussion as the New Governance process was not initiated pursuant to this statute but was initiated and designed by the stakeholders themselves.

${ }^{131}$ See id. at 393.

${ }^{132}$ See id. at 425 .

${ }^{133}$ Collaborative Agreement, supra note 13, para. 1. 
In short, the Cincinnati example demonstrates the use of nearly all of the prominent means of promoting the baseline conditions necessary for meaningful participation to take place. Another illustration of how the two baseline conditions can be established outside of the courtroom is provided by the gender-diversity initiative among science and engineering faculty at the University of Michigan, as discussed by Susan Sturm.

In this case, several different architects helped to affirmatively define the goal of increasing gender diversity and to impose it on local stakeholders and the university employees and administrators. Congress had authorized an independent federal science agency to provide grant funding for participating universities. ${ }^{134}$ The science agency made individual universities, such as Michigan, sign a contract setting forth the framework goals and worked with the universities to set appropriate assessment measures. ${ }^{135}$ The University of Michigan then made the goal relevant to its administrators and employees. In part, the Michigan initiative did so by framing the promotion of gender diversity as aligned with "core institutional values,"136 such as the advancement of science, which served to emphasize how the goal of diversity was in fact common to all stakeholders.

A form of hybridity may also have been at work. Courts and legislatures had previously set framework goals of gender equality in the workplace, which may have reinforced for the universities, administrators, and perhaps even some employees that the goal of gender diversity was common to their interests of avoiding discrimination lawsuits. ${ }^{137}$

In terms of establishing the second baseline condition-the recognition of the marginalized stakeholders' contribution to the process-the significance of input by women was also made clear to the other stakeholders, given the nature of the goal itself. Aligning gender diversity with core institutional interests, such as the overall advancement of science, further reduced "backlash" from potentially hostile stakeholders ${ }^{138}$ and made it easier for women to advocate for change. ${ }^{139}$ This illustrates how the proper definition of a common goal can support the recognition of the marginalized stakeholders' contributions.

In addition, the university used proxies such as experts on gender and race, as well as deans and other administrators, who were able to promote women's interests because they had "knowledge, influence, and credibility." 140 The university also supported direct stakeholder input from women through surveys and focus groups, ${ }^{141}$ as well as through confidential channels of communication. ${ }^{142}$

\footnotetext{
${ }^{134}$ Sturm, supra note 67 , at $272-73$.

${ }^{135} \mathrm{Id}$. at $314-15$.

${ }^{136} \mathrm{Id}$. at $302-03$.

${ }^{137} \mathrm{Id}$. at 305 .

${ }^{138} \mathrm{Id}$. at $308-09$.

${ }^{139} \mathrm{Id}$. at 310 .

${ }^{140} \mathrm{Id}$. at $283-84,287$.

${ }^{141} \mathrm{Id}$. at 284-85.

${ }^{142} \mathrm{Id}$. at 291.
} 


\section{Active and Passive Promotion of Meaningful Participation}

The preceding analysis suggests some important lessons about promoting meaningful participation outside of the courtroom. In short, the case studies echo the theoretical analysis of Part III and its conclusion that structural support for meaningful participation is needed to overcome the conflict inherent to New Governance systems and other barriers faced by marginalized stakeholders. Further, while the approaches to promoting meaningful participation range from relatively passive approaches to very active ones, the case studies strongly indicate that passive approaches alone are unlikely to be sufficient. The recognition that meaningful participation by marginalized stakeholders does not inevitably occur, but requires intervention, is an important one as it is frequently overlooked, leaving the model susceptible to producing merely cosmetic processes.

A review of the approaches to establishing the baseline conditions reveals a distinction between passive and active promotion of meaningful participation. A passive architect, for example, might seek to institute a New Governance system where both baseline conditions already exist and where no affirmative act on the part of the architect is necessary to establish the conditions. Such an architect might seek out situations where a destabilizing event has surfaced a common goal and where marginalized stakeholders are already adequately represented by proxies or well mobilized.

Such a confluence of conditions is likely to be rare, however. Where it does exist, more intensive support for meaningful participation will almost certainly still be necessary. Cincinnati, for example, experienced a severely destabilizing event with tragic, widespread consequences, and marginalized stakeholders in that situation were represented by proxies. Even so, the baseline conditions were also promoted through various other means, including hybridity, the facilitation of direct stakeholder participation, and penalty defaults. Given the ambitious goals of New Governance to challenge the status quo on the basis of the perspectives of marginalized stakeholders, it seems unlikely that purely passive systems could overcome the challenges to meaningful participation faced by marginalized stakeholders. ${ }^{143}$

At the active end of the spectrum are court-based systems, where extraordinary powers are wielded over participants in order to promote the baseline conditions. While such powers may be necessary where the baseline conditions are wholly absent, as in the case of destabilization lawsuits, active New Governance systems are not limited to court settings. Legislatures, administrative agencies, and other institutions with regulatory powers can also actively promote the baseline conditions. Private organizations can serve this function as well. Employers, for example, wield strong influence over their employees and have significant ability to promote the baseline

\footnotetext{
${ }^{143}$ Ford, supra note 3, at 484-85 ("[T] he development of active contestation and deliberation within New Governance structures cannot be presumed. It must be fostered, ensured, and protected.").
} 
conditions within their own institutions. Grant-making institutions can also play instrumental roles in promoting meaningful participation by providing soft incentives for others to carry out goals that include the interests of marginalized stakeholders.

Each of these types of entities has some ability to promote the baseline conditions in New Governance systems. They can impose framework goals that incorporate the interests of marginalized stakeholders, motivate others to pursue those goals, support the ability of proxies to adequately represent marginalized stakeholders, and support mobilization efforts. Active architects may work on multiple levels, either in concert or in tandem. In the University of Michigan case study, for example, three levels of architectsCongress, a federal agency, and a university - actively promoted the meaningful participation by marginalized stakeholders.

The case of Wisconsin's innocence reform initiative presents another example of multiple architects actively working to promote meaningful participation in tandem, if not in concert. The Wisconsin Supreme Court imposed new standards for eyewitness-identification procedures, and the legislature responded by requiring local law-enforcement agencies to use New Governance-type methods to revise their procedures to meet legal standards. ${ }^{144}$ In addition, the Wisconsin Innocence Project and a state legislator were instrumental in encouraging, designing, and implementing the New Governance process on the local level. ${ }^{45}$ All of these architects actively promoted the meaningful participation of marginalized stakeholders.

The question of who wields the power to actively promote meaningful participation, and whether they are willing to use that power to promote meaningful participation, is a critical but often overlooked aspect of the discussion. ${ }^{146}$ In her analysis of the participation of inner-city residents in the urban-development process, Audrey McFarlane suggests that participation must be "properly understood as not only a form of participatory inclusion, but also as a struggle for redistribution of power." 147 To promote meaningful participation by marginalized stakeholders is therefore to promote a shift in power. Given the barriers that exist to altering dominant norms based on the input of traditionally unempowered stakeholders, it is not surprising that active promotion of meaningful participation is necessary, or that without active promotion, cosmetic participation is likely to result.

The use of power to promote meaningful participation is, notably, a key point at which the analogy between New Governance systems and business transactions breaks down. While the same baseline conditions are necessary to promote meaningful participation in both, the consequences of a failed New Governance system are more significant than the consequences of a

${ }^{144}$ See Kruse, supra note 33, at 647-48.

145 See id. at 707-19.

${ }^{146}$ Cohen, supra note 62 , at 533 ("[T]he governance paradigm tends to bracket power asymmetries and to view the public sphere as a rather depoliticized arena of collaboration among generic "stakeholders." ").

147 See McFarlane, supra note 45 , at 929. 
failed business transaction. The New Governance approach is meant to decide legal and policy decisions, and to avoid the harms of cosmetic processes, architects must be both able and willing to actively promote meaningful participation by marginalized stakeholders.

\section{E. A Baseline Theory of Prevention}

Ultimately, the baseline-conditions framework may be used to thwart the occurrence of cosmetic processes, as well as to aid in designing systems that are more likely to improve outcomes and accountability.

The baseline-conditions framework for promoting meaningful participation gives rise to a threshold test for analyzing, in any given instance, whether the New Governance approach is an appropriate method of problem solving, or whether it is too susceptible to producing a cosmetic process. The test is that if the baseline conditions exist or can be established, then the New Governance approach may be suitable for the circumstances. If the baseline conditions do not exist and are unlikely to be established, then the risk of producing a merely cosmetic process is unacceptably high, and the New Governance model should be rejected in favor of other problem-solving methods.

This test constitutes a baseline theory of prevention against cosmetic processes. The circumstances under which Cincinnati's police-reform initiative was undertaken provide a helpful illustration. In this instance, the appropriate point at which to apply the baseline theory of prevention would have been when the court and the litigants first considered whether to engage in a New Governance-style settlement process.

Before deciding that a New Governance process was appropriate for the circumstances, the court and the litigants might have first considered whether the two baseline conditions existed. In other words, they might have asked: Is there a common goal toward which all of the stakeholders are motivated, and are the contributions of the city's African American residents likely to be recognized by other stakeholders as valuable?

As suggested by the preceding analysis, the answer to both questions would likely have been yes. Many different factors were in place that would support the two baseline conditions: destabilizing events, hybridity, penalty defaults, architect-imposed goals, legitimized proxies, and the fact that the proxies were endowed with veto power over the outcome. These conditions, taken together, would have strongly indicated that the New Governance model had the potential to produce meaningful participation.

To use another example, consider the case study of community health centers that provide patients with a majority of seats on their governing boards. Federal legislation defines the goal of improving health care through patient participation. It also provides the motivation of grant funding, which is especially promising since participants are self-selecting; those who apply are likely to be strongly inclined to share the goal. Further, even if some employees might be reluctant to embrace the goal of patient participation, 
the center's power over its employees would still enable it to promote the goal. The legislation's definition of the goal, the soft motivation of the grant funding, and the employer's coercive power thus all strongly support the first baseline condition, or the creation of motivation toward a common goal.

The second baseline condition, or recognition of the marginalized stakeholder's contribution to the goal, was also supported. The value of the patients' input is apparent. The legislation specifically affords them a majority of seats on the board, building direct stakeholder participation into the system and affording the marginalized stakeholders a very precise amount of weight-board control. Again, because the center wields significant power over employees, other opportunities to promote the recognition of patient input also exist. All of these factors indicate strong promise for meaningful participation under these circumstances.

The threshold test, in short, assesses whether the two baseline conditions are present and whether they can be induced. This entails an evaluation of whether an architect (or architects) is able and willing to exert the power necessary to support these conditions. Each of these questions is critical to assessing whether the New Governance model is likely to produce a participatory process with integrity or whether it is too susceptible to subversion.

Admittedly, at best, any prospective application of the threshold test provides simply a rough assessment, and as discussed earlier, the baseline conditions do not guarantee that meaningful participation will occur, that the participants will ultimately agree on a resolution, or that participants' needs will be adequately addressed. In addition, the threshold test does not address the difficult questions of identifying all stakeholders, ensuring that participation will be robust, or ensuring that stakeholders will remain sufficiently motivated over the extended period of time necessary to implement a New Governance process. ${ }^{148}$ Consequently, the baseline theory of prevention serves only as a threshold consideration of whether conditions might possibly support meaningful participation, and thus whether a New Governance process should even be considered.

Despite its limitations, even a threshold assessment tool is urgently needed. Learning to distinguish situations where there is some possibility that meaningful participation will occur, from those where it is not, is critically important to reducing cosmetic processes. A third example demonstrates this principle. In a case study presented by Douglas Nejaime, a school district invited both Christian fundamentalists and gay-rights groups

${ }^{148}$ As mentioned in the analogy of business transactions, in the car repair context, the need for ongoing motivation in the face of changing circumstances is a concern. As noted, this article focuses primarily on a threshold assessment of whether a New Governance system has the potential to provide meaningful participation (an assessment made at a particular point in time, before the New Governance system is embarked upon), and not on the challenges of sustaining or implementing the process itself. For a discussion of some ways to sustain motivations over time, see Sturm, supra note 67, at 327 (discussing "organizational catalysts," capacity building, and other means of supporting sustained implementation). 
to assist in developing a sexual-education curriculum. ${ }^{149}$ School administrators might have first considered whether the stakeholders shared a common goal, or whether one could be induced. The two groups held such deeply divergent ideological views about the substance of that curriculum ${ }^{150}$ that they effectively shared no common goal; rather, each wished the final outcome to exclude the other side's perspective.

According to the baseline theory of prevention, a process lacking a common goal and recognition by one side of the other's contribution is too likely to end without agreement, and to produce merely cosmetic participation. Had school administrators applied the baseline-conditions test and realized that the circumstances at hand were not conducive to meaningful participation, it could have ruled out the use of New Governance as inappropriate for those circumstances and prevented a significant loss of time and effort.

Alternatively, school administrators could also have considered whether the baseline conditions could be better promoted. For instance, since a common goal was not apparent, school administrators might have asked whether they could define a common goal for the participants that included both perspectives, such as a curriculum presenting both viewpoints. Motivations toward that goal would also need to be established, so administrators might have considered imposing a penalty default that would take effect if the sides did not agree, such as the imposition of a curriculum that neither side would be satisfied with.

The administrators would also have needed to promote the recognition by each group of what the other group contributed to the goal. Toward that end, they might have specified that in order to avoid the penalty default, both sides must agree on the curriculum, so that each side would have veto power. Administrators might also have considered additional steps, such as supporting the process with alternative-dispute-resolution processes and ensuring face-to-face meetings.

If both sides were willing to negotiate under these conditions, perhaps meaningful participation might have been possible. Were administrators unwilling or unable to take these or other steps to promote the baseline conditions, however, they would need to accept that the lack of the baseline conditions made these circumstances a poor candidate for a New Governance process.

The baseline-conditions framework can thus be applied not only to identify situations in which the New Governance process might not be appropriate but to design systems that have a significantly greater likelihood of producing meaningful participation. A significant component of this test is that the architect must consider how he or she might try to promote the baseline conditions, thus forcing the architect to consider whether the archi-

\footnotetext{
${ }^{149}$ Nejaime, supra note 28 , at 336.

${ }^{150} \mathrm{Id}$. at 358 ("[T] he intensely adversarial legal and political relationship between these two movements poses a perhaps insurmountable challenge to the consensus norm.").
} 
tect itself is both able and willing to exert the necessary power over the participants. If the architect were not, the architect would recognize the need to reject the New Governance model as too susceptible to producing a cosmetic result.

Assessing the risk of a cosmetic process at the outset could drastically reduce the number of cosmetic processes undertaken, yet it is a frequently neglected step. This may be in part due to the fact that a comprehensive assessment mechanism has not yet been formulated. A variety of theories for distinguishing when New Governance is appropriate and when it is not have been proposed. For example, one thesis suggests that New Governance should be pursued where participants face "urgent" problems and seek "joint accountability." 151 Another theory suggests applying the New Governance model when participants share readily observable common ground and trust, and do not have strong ideological differences.

Additional theories exist, ${ }^{152}$ and each formulation valuably describes a subset of situations in which the New Governance model might be fruitfully applied. None individually, however, provides a comprehensive vision; nor do these existing theories collectively provide a cohesive vision. The baseline-conditions framework is consistent with each of these other theories, cohesively capturing the concepts embedded into them within a single framework, while also building in specific protections against the abuse of cosmetic processes.

\section{Conclusion}

Given the barriers to the meaningful participation of poor people in New Governance processes, it is tempting to conclude that meaningful participation is likely to occur only under extremely rare circumstances, and that consequently, most problems of poverty law are unsuitable for the New Governance approach. Further, even the most promising proposals discussed in this article do not guarantee that participation will be meaningful or that the concerns of marginalized stakeholders will be adequately addressed.

Even so, the threshold test serves some critical purposes. When application of the test results in the rejection of the New Governance approach as inappropriate for a particular set of circumstances, a cosmetic process is

${ }^{151}$ Dorf \& Sabel, supra note 1 , at 322.

${ }^{152}$ Another thesis holds that a New Governance-style approach is suitable when all participants see personal benefit in changing the status quo, but are uncertain how to make change and need others' input. See Simon, supra note 69, at 209; see also James S. Liebman \& Charles F. Sabel, The Fragile Promise of Provisionality, 28 N.Y.U. Rev. L \& Soc. Chınge 369,370 (2003) ("People disserved by the current system are sufficiently aggrieved by the resulting costs that it is worth their while to coalesce to disentrench established interests, provided that there is a minimally acceptable prospect of success and accountability."). A fourth proposal holds that New Governance methods should only be pursued when participants are aware that they do not have strong default positions. See Sabel \& Simon, supra note 57, at 1100 . 
likely to have been thwarted. Moreover, when the test indicates circumstances supportive of meaningful participation, an opportunity for effectuating substantive change might be seized. While no single success will resolve the problems of deeply entrenched marginalization, even rare opportunities for incremental change should not be lightly dismissed. Every instance of a successful New Governance process serves to embed marginalized voices more deeply and systemically into decision-making processes. Furthermore, the learning-by-doing component of the New Governance model supports scaling up and adapting successful experiments for use in other contexts, potentially broadening the impact of even small-scale, localized change.

While much work remains to be done to bring this vision to reality, articulating the vision is an important step. Reversing long-standing inequities will require as many tools as can be imagined, and New Governance is one. 
ApP. 1

\begin{tabular}{|c|c|c|c|c|}
\hline & Two Bas & nditions $M$ & ist Before Meaningful & cipation Is Possible. \\
\hline & & $\begin{array}{r}\text { Condition 1: } \\
\text { A C }\end{array}$ & $\begin{array}{l}\text { totivations Toward } \\
\text { nmon Goal }\end{array}$ & $\begin{array}{l}\text { Condition 2: Recognition of } \\
\text { Contributions }\end{array}$ \\
\hline & & $\begin{array}{l}\text { Establishing a } \\
\text { Common Goal }\end{array}$ & $\begin{array}{c}\text { Establishing Motivation } \\
\text { Toward the Goal }\end{array}$ & $\begin{array}{l}\text { Establishing Recognition } \\
\text { of Contributions }\end{array}$ \\
\hline & $\begin{array}{l}\text { Business } \\
\text { transactions }\end{array}$ & $\begin{array}{l}\text { Participants define } \\
\text { common goal. }\end{array}$ & $\begin{array}{l}\text { Participants define } \\
\text { motivations. }\end{array}$ & $\begin{array}{l}\text { Contributions easily } \\
\text { recognized. }\end{array}$ \\
\hline Passive & $\begin{array}{l}\text { New } \\
\text { Governance } \\
\text { systems outside } \\
\text { of the courts }\end{array}$ & $\begin{array}{l}\text { "Destabilizing } \\
\text { event" creates } \\
\text { common goal. } \\
\text { - Participants } \\
\text { define common } \\
\text { goal, strongly } \\
\text { supported by } \\
\text { facilitators. } \\
\\
\\
\text { Architect } \\
\text { imposes } \\
\text { common } \\
\text { "framework" } \\
\text { goal. }\end{array}$ & $\begin{array}{l}\text { - "Destabilizing } \\
\text { event" creates } \\
\text { motivation. }\end{array}$ & $\begin{array}{l}\text { - Rely on proxies, if } \\
\text { appropriate. } \\
\text { Rely on mobilization, if } \\
\text { appropriate. } \\
\text { Architect facilitates } \\
\text { appropriate reliance on } \\
\text { proxies/mobilization. } \\
\text { Architect defines } \\
\text { "framework" goal that, } \\
\text { by its nature, affords } \\
\text { weight to participants" } \\
\text { input. } \\
\text { Architect defines a } \\
\text { specific weight to be } \\
\text { afforded to participants" } \\
\text { input. }\end{array}$ \\
\hline Active & $\begin{array}{l}\text { Court-based } \\
\text { New } \\
\text { Governance } \\
\text { system }\end{array}$ & $\begin{array}{l}\text { Legal system } \\
\text { imposes common } \\
\text { goal. }\end{array}$ & $\begin{array}{l}\text { Legal system imposes } \\
\text { motivation. }\end{array}$ & $\begin{array}{l}\text { Legal systems affords } \\
\text { significant weight to } \\
\text { plaintiff's' input. }\end{array}$ \\
\hline
\end{tabular}

